University of Thi-Qar Journal Vol.11 No.2 June 2016

Web Site: https://jutq.utq.edu.iq/index.php/main Email: journal@jutq.utq.edu.iq

\title{
Reducing the effects of paracetamol-induced hepatic damage in rat With fluvastatin drug
}

\author{
https://doi.org/10.32792/utq/uti/vol11/2/4
}

Mahdi M. Thuwaini ${ }^{*}$ and Hanaa S. Kadhem ${ }^{* *}$ Hatem A. Hatem $^{* * *}$
*Ph.D., College of Nursing, University of Thi- Qar; E- Mail address; hayder9015@yahoo.com

** Ph.D., College of Science, Biology Department / University of Basra

$$
\begin{aligned}
& * * * \text { Ph.D., College of Medicine, Anatomy\&Histology } \\
& \text { department, University of Thi- Qar. }
\end{aligned}
$$

\begin{abstract}
The goal of current study was to actualization the protective effect of the probability of Fluvastatin hepatoprotection. Paracetamol (PCM) overdose can cause hepatotoxicity with oxidative stress as one of the possible mechanisms mediating the event. In present study, the effects of Fluvastatin $(10 \mathrm{mg} / \mathrm{kg})$ and $(20 \mathrm{mg} / \mathrm{kg})$ on PCM-induced hepatotoxicity were examined. Rats were divided randomly into five groups containing 9 rats each. The control group received normal saline (the vehicle). Other groups were treated with Fluvastain alone $(20 \mathrm{mg} / \mathrm{kg})$, PCM alone $(600 \mathrm{mg} / \mathrm{kg})$, $(600 \mathrm{mg} / \mathrm{kg}$ PCM $+10 \mathrm{mg} / \mathrm{kg}$ Fluvastatin), and $(20 \mathrm{mg} / \mathrm{kg} \mathrm{PCM}+20 \mathrm{mg} / \mathrm{kg}$ Fluvastatin) respectively, for 4 weeks. Paracetamol induced male rat hepatotoxicity represented by significant decline in the serum total albumin $(\mathrm{P}<0.05)$. However, the study appeared significantly increment $(\mathrm{P}<0.0001)$, bilirubin, ALT, AST and ALP as shown in group2 (induction group) in comparison with group1 (control group). However, simultaneous administration of fluvastatin $(10 \mathrm{mg} / \mathrm{kg}$ and $20 \mathrm{mg} / \mathrm{kg})$ with paracetamol, significantely was attenuated the adverse changes in the serum total albumin, bilirubin, ALT IU/L, AST, and ALP.
\end{abstract}




\section{University of Thi-Qar Journal Vol.11 No.2 June 2016}

Web Site: https://jutq.utq.edu.iq/index.php/main Email: journal@jutq.utq.edu.iq

On the other hand, the biochemical observations were supported by histopathological examination of liver sections. Where, showed marked attenuated the severity of paracetamol -induced hepatotoxicity, However, all these toxic effects were improved by administration of fluvastatin, but didn't bring them to the control limits.

Keywords: Fluvastatin, Hepatotoxicity, Paracetamol, Hepatoprotection, histopathology.

Corresponding Author: Mahdi M.T. Histopathologist, Department of basic medical sciences , Thi-Qar University. Nursing College, E-mail: hayder9015@yahoo. Com. Tel: +9647802898872.

\section{Introduction}

The liver is a major organ for metabolism of foreign substances and also functionally interposed between the site of resorption and the systemic circulation. These conditions render the liver not only the most important organ for detoxification of foreign substances but also a major target of their toxicity. In other words, Liver organizes many important metabolic functions, and any injury causes distortion of these metabolic functions (1).

Paracetamol or acetaminophen is an analgesic and antipyretic widely used. Extract of tar, which is the active metabolite of phenacetin, unlike phenacetin, paracetamol does not appear that carcinogen in any way. Paracetamol is well tolerated, and does not have many side symptoms of aspirin, which is available on the table that is, it does not require a prescription in order to distract. It is generally for the treatment of fever, headache, aches, pain and light is used. Paracetamol also be useful in dealing with other severe pain in conjunction with NSAIDs or with opioid analgesics (2) and enters paracetamol essential ingredient in many recipes cold and flu. Although it is safe to humans in doses recommended limits, but that excessive doses are likely to cause poisoning liver; the first cause of liver failure in the West is paracetamol poisoning, which is behind most of the increase the dose in a number of countries in the world $(3,4,5,6)$ and increases the threat against drinking alcohol.

However, Toxic dose of paracetamol varies a great variety. In adults, single doses above 10 grams or $200 \mathrm{mg} / \mathrm{kg}$ can cause poisoning(2,7), and can be poisoned also occur when several small doses abuse throughout the day a total higher than this amount (2). In children one dose higher than the 


\section{University of Thi-Qar Journal Vol.11 No.2 June 2016}

Web Site: https://jutq.utq.edu.iq/index.php/main Email: journal@jutq.utq.edu.iq

$200 \mathrm{mg} / \mathrm{kg}$ can cause poisoning (8). But paracetamol overdose rarely lead to illness or death in children. However, paracetamol, traditionally, it is believed that a minimum of $7.5-10 \mathrm{~g}$ is needed to produce hepatic necrosis in an adult. And rarely deals with a child on the amount of paracetamol once require treatment. But most cases of poisoning in children come from the chronic use of paracetamol (2).

When we use one gram of paracetamol four times a day, one third of patients can be more than they have liver function test values three times the normal values, but it is uncertain if it can lead to liver failure (9). Furthermore, Due to its high tolerance and its availability over-the-counter, acute overdose of the drug, causing fulminant hepatic damage is common (10). In cases of paracetamol overdose, the sulfate and glucuronide pathways become saturated, and more paracetamol is shunted to the cytochrome P450 system to produce NAPQI. As a result, hepatocellular supplies of glutathione become depleted, as the demand for glutathione is higher than its regeneration.(11) NAPQI therefore remains in its toxic form in the liver and reacts with cellular membrane molecules, resulting in widespread hepatocyte damage and death, leading to acute hepatic necrosis.(12) In animal studies, hepatic glutathione must be depleted to less than $70 \%$ of normal levels before hepatotoxicity occurs(13).

However, many of the drugs used for hepatoprotectiion in liver paracetol poisoning such as angiotensin converting enzyme inhibitors or angiotensin receptor II antagonists, hydrogen-rich water, resveratrol, melatonin, quercetin and other flavonoids $(14,15,16,17,18,19)$. Furthermore, recent research also displayed that a wide range of plants can reduce or detoxify toxins and protect hepatic system from the toxic effects of drugs and chemicals (20-21).

However, flustatin are specific inhibitors of 3-hydroxy-3methylglutaryl coenzyme A (HMG-CoA) reductase, the rate-limiting enzyme in cholesterol biosynthesis In addition to the effects of cholesterol-lowering(22). Statins also have pleotropic effect including; anti-inflammatory, anti-proliferative, anti-thrombotic, anti-oxidative, anti-cancer properties, and immunomodulatory actions in vitro and in vivo as well as that statins can reduce triglycerides to the liver and improves hepatic steatosis (23), so improving NASH -related fibrogenesis, clinically, the therapeutic role of statins in the treatment of patients with NASH still controversial(24), even 


\section{University of Thi-Qar Journal Vol.11 No.2 June 2016}

Web Site: https://jutq.utq.edu.iq/index.php/main Email: journal@jutq.utq.edu.iq

though he had been told that statins can improve hepatic steatosis and lower activity as a result of NAFLD(25), however, remains its efficiency against fibrosis is unclear.

Therefore, the present study was designed to assess the protective effect of orally administered fluvastatin against paracetamol-induced hepatotoxicity in rats. The effects were determined by measuring the levels of liver's function enzymes, albumin, bilirubin and histological change analysis.

\section{Materials and methods}

\section{Experimental animals}

Male Wistar rats weighing (12 week old) between 150 and $200 \mathrm{~g}$ were used for this study. The animals were obtained from animal center of Thi-Qar university Icollege of science The animals were kept in a well-ventilated animal house, at a temperature of $22 \pm 2{ }^{\circ} \mathrm{C}$ and exposed to $12 \mathrm{~h}$ light and $12 \mathrm{~h}$ dark/ day, All animal were allowed to take standard food with a constant source of water were given ad libitum.

\section{Drugs}

Fluvastatin (Actavis, Barnstaple, EX32, and UK) and Paracetamol drug (SDI Co, Iraq) were dissolved in normal saline before use.

\section{Experimental design}

Animals were divided randomly into five groups (9 each), the first group was given normal saline (the vehicle) $0.5 \mathrm{ml} /$ animal /daily i.p. for $4 \mathrm{wks}$, to serve as control group. The second group (induction) was given paracetamol (PCM) $600 \mathrm{mg} / \mathrm{kg}$ alone, was administered orally three times weekly for 8 weeks. The third group was received fluvastatin $20 \mathrm{mg} / \mathrm{kg}$ day alone by gavage for 8 weeks as a single daily oral dose, while the fourth group rats were treated with fluvastatin $10 \mathrm{mg} / \mathrm{kg} /$ day and $600 \mathrm{mg} / \mathrm{kg}$ PCM. Animals in Group five were treated with fluvastatin $20 \mathrm{mg} / \mathrm{kg} /$ day and $600 \mathrm{mg} / \mathrm{kg}$ PCM. On end experiment, all animals were weighed and anaesthetized with diethyl ether.

\section{Biochemical assay}




\section{University of Thi-Qar Journal Vol.11 No.2 June 2016}

Web Site: https://jutq.utq.edu.iq/index.php/main Email: journal@jutq.utq.edu.iq

At the end of the treatment period, all animal were killed by neck dislocation after light anesthesia. Blood samples were taken by cardiac puncture. Where, the collected blood samples were allowed to clot. Sera were removed by centrifugation at $2500 \mathrm{rpm}$ for $15 \mathrm{~min}$. Then serum samples were processed to determine the activities of aspartate aminotransferase (AST), alanine aminotransferase (ALT), alkaline phosphatase (ALP), total bilirubin and albumin, using a spectrophotometric autoanalyzer (Olympus AU-2700).

\section{Histological examination}

The abdomen was opened, and the livers were removed and cleaned. Liver tissue samples were fixed in 10\% formalin solution and after excessive washing in $70 \%$ alcohol, the tissue was processed for paraffin embedding and $5 \mu$ thick paraffin sections were stained with hematoxylin and eosin.

\section{Statistical analysi}

Results were analyzed by one-way Analysis of Variance (ANOVA). Values of $\mathrm{P}<0.05$ were considered statistically significant (26).

\section{Results}

The results demonstrated that the paracetamol hepatotoxicities, as well as the effect of fluvastatin on serum levels of albumin, bilirubin and liver enzymes (ALT, AST and ALP) in rats treated with APAP is reported in Table 1. Where paracetamol hepatotoxicity was correlated with significant decrease in the serum albumin $(\mathrm{mg} / \mathrm{dl}) \mathrm{P}<0.05$. Conversely, the current study was appeared significantly increased $(\mathrm{P}<0.0001)$, bilirubin $(\mathrm{mg} / \mathrm{dl})$, ALT, AST and ALP as shown in group2 (induction group) in comparison with group1 (control group), but when using of fluvastatin alone in healthy rats (group3) caused little insignificant changes in serum total bilirubin, albumin, ALT, AST and ALP. Whilst, immediate administrations of fluvastatin (low dose $10 \mathrm{mg} / \mathrm{kg}$ and high dose $20 \mathrm{mg} / \mathrm{kg}$ ) with paracetamol resulted significant reduction the adverse changes in the serum total bilirubin, ALT, AST and ALP $(\mathrm{P}<0.001)$. While, Concomitant oral administration of low and high dose of fluvastatin with paracetamol (group 4 and 5) showed significant increment $(\mathrm{P}<0.05)$ in the mean values of serum total albumin. As compared with paracetamol -treated rats. However, it didn't return them to the normal limits. 


\section{University of Thi-Qar Journal Vol.11 No.2 June 2016}

Web Site: https://jutq.utq.edu.iq/index.php/main Email: journal@jutq.utq.edu.iq

Histopathological examination of liver sections of control group showed normal hepatic tissue(no histological changes) (Figure.1). Disarrangement of normal hepatic cells with necrosis and vacuolization. Morphological changes including hepatic cells degeneration, cell desquamation and necrosis were clearly observed in the paracetamol-treated rats (Figure.2). The cellular debris in the peripheral hepatic zone was prominent. In addition, dilatation of hepatic central vein, congestion of hepatic blood vessels were detected only in the livers of paracetamol-treated rats (Figure 3). Rat treated with two doses of fluvastatin $(10 \mathrm{mg} / \mathrm{kg}$ and $20 \mathrm{mg} / \mathrm{kg}$ B.w.) simultaneously with paracetamol intoxication, was showed significantly reduced the Liver damages, seen after paracetamol intoxication. In spite of the presence of mild cells degeneration and epithelial vacuolization, Cellular desquamation was minimal and hepatic sinusoid maintained a better morphology compared with the paracetamol group (Figure.5).

Table1: Effect of administration of low dose $(10 \mathrm{mg} / \mathrm{kg} / \mathrm{day})$ and high dose $(20 \mathrm{mg} / \mathrm{kg} / \mathrm{day})$ of Fluvastatin on Paracetol induced hepatotoxicity in rats.

\begin{tabular}{|l|l|l|l|l|l|}
\hline $\begin{array}{l}\text { Parameters } \\
\text { groups }\end{array}$ & $\begin{array}{l}\text { Bilirubin } \\
\text { mg/dl }\end{array}$ & $\begin{array}{l}\text { Albumin } \\
\text { g/dl }\end{array}$ & $\begin{array}{l}\text { ALT } \\
\text { U/L }\end{array}$ & $\begin{array}{l}\text { AST } \\
\text { U/L }\end{array}$ & ALP U/L \\
\hline G1 & $0.56 \pm$ & $4.52 \pm$ & $56.33 \pm$ & $73.89 \pm$ & $139.77 \pm$ \\
\hline G2 & $1.80 \pm *$ & $2.98 \pm *$ & $\begin{array}{l}162.82 \pm \\
*\end{array}$ & $\begin{array}{l}232.56 \pm \\
*\end{array}$ & $249.25 \pm *$ \\
\hline G3 & $0.58 \pm$ NS & $4.48 \pm$ NS & $\begin{array}{l}55.67 \pm \\
\text { NS }\end{array}$ & $\begin{array}{l}74.66 \pm \\
\text { NS }\end{array}$ & $\begin{array}{l}141.85 \pm \\
\text { NS }\end{array}$ \\
\hline G4 & $1.71 \pm \#$ & $3.03 \pm \#$ & $\begin{array}{l}156.95 \pm \\
\#\end{array}$ & $\begin{array}{l}229.22 \pm \\
\#\end{array}$ & $244.12 \pm \#$ \\
\hline G5 & $1.07 \pm \#$ & $3.51 \pm \#$ & $\begin{array}{l}112.16 \pm \\
\#\end{array}$ & $\begin{array}{l}136.79 \pm \\
\#\end{array}$ & $9.33 \pm \#$ \\
\hline
\end{tabular}

Results are presented as Mean \pm SD

* Significant change $(\mathrm{P}<0.05)$.compared to control vehicle group.

\#: Significant change $(\mathrm{P}<0.05)$ compared to induction group.

NS: Non-significant 
Web Site: https://jutq.utq.edu.iq/index.php/main Email: journal@jutq.utq.edu.iq

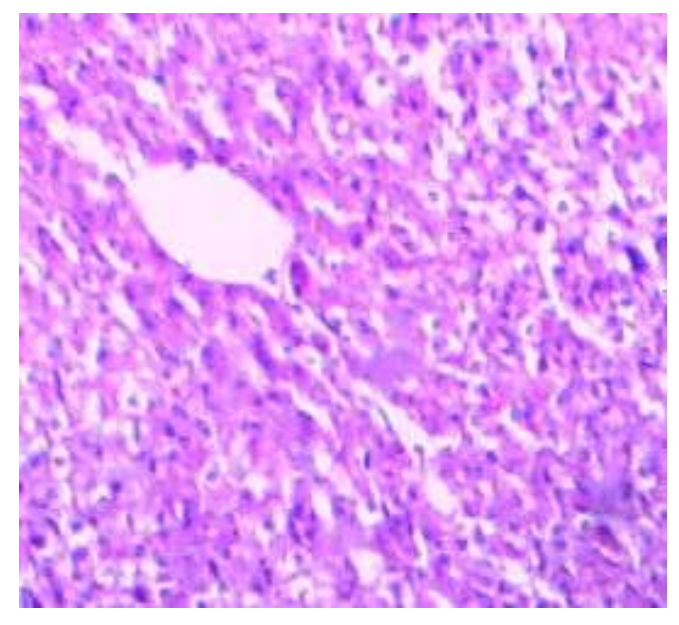

Figure 1:- sections of control group showed normal cellular architecture with distinguished hepatic cells, sinusoidal spaces and central vein with clear-cut hepatic structural architecture

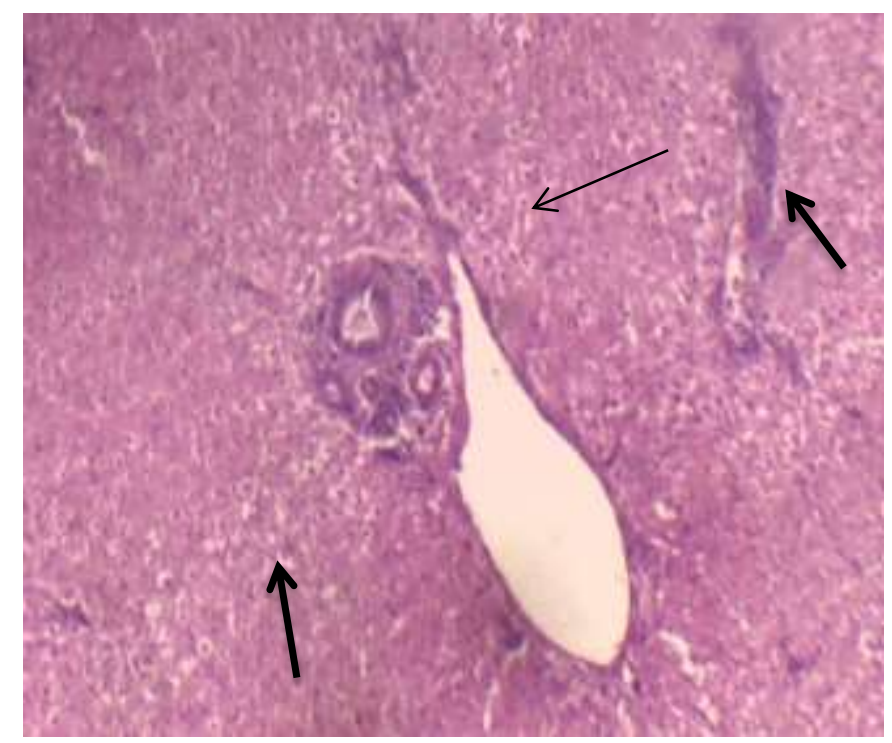

Figure 2:- Section in the liver of the rats treated with paracetamol, marked, Disarrangement of normal hepatic cells with necrosis( Thin arrow), 


\section{University of Thi-Qar Journal Vol.11 No.2 June 2016}

Web Site: https://jutq.utq.edu.iq/index.php/main Email: journal@jutq.utq.edu.iq

and vacuolization. Morphological changes including hepatic cells degeneration, cell desquamation clearly observed (thick arrow).

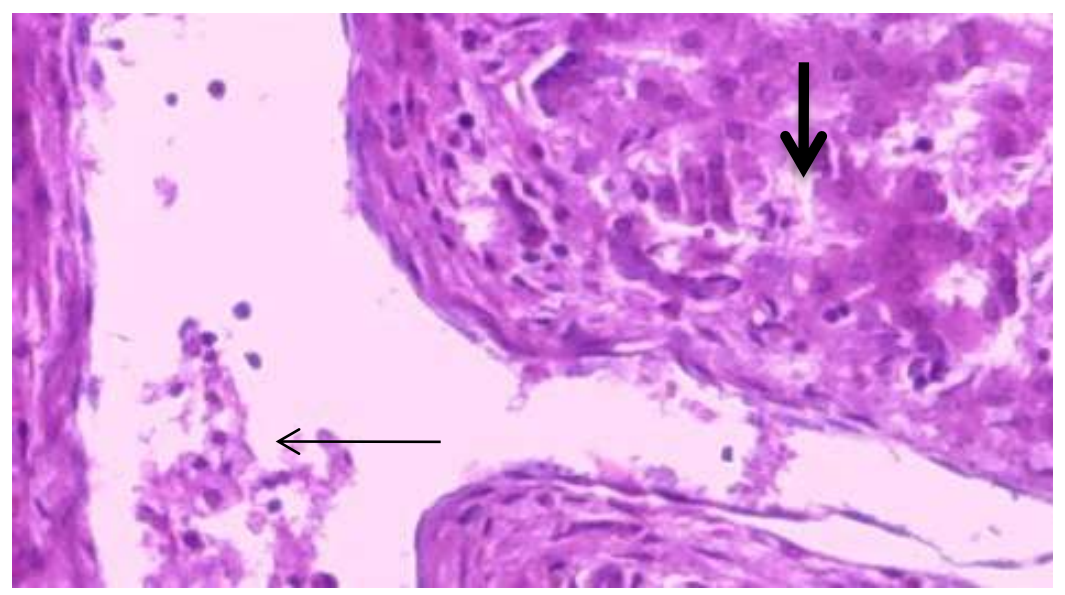

Figure 3:- Section in rat's liver treated with PCM. The cellular debris in the hepatic central vein was prominent. In addition, dilatation hepatic central vein (Thin arrow), degeneration number of hepatic cells (thick arrow).

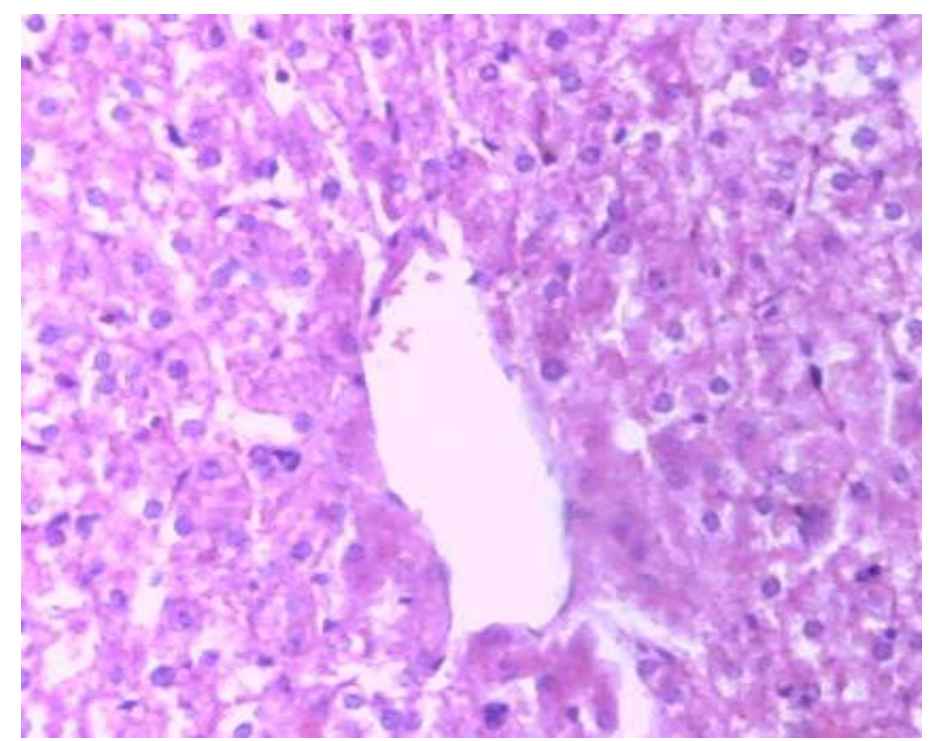

Figure 4:- Section in the liver of rat treated with PCM and Fluvastatin) showed mild inflammatory cells In spite of the presence of mild cells degeneration and epithelial vacuolization, Cellular desquamation was 


\section{University of Thi-Qar Journal Vol.11 No.2 June 2016}

Web Site: https://jutq.utq.edu.iq/index.php/main Email: journal@jutq.utq.edu.iq

minimal and hepatic sinusoid maintained a better morphology compared with the paracetamol group

\section{Discussion}

Paracetamol-induced acute hepatocellular injury as an experimental model of drug-induced acute hepatic necrosis is stabile $(27,28)$. However, in reviewing the literature showed acute hepatocellular injury there is an increment in plasma transaminases, in which ALT is predominant. But the high level of enzyme in intrahepatic cholestasis is also seen and there is a predominant elevation of plasma ALP activity (29). Anyhow, Paracetamol is commonly and widely used analgesic and antipyretic drug. It was safe when used in a therapeutic dose. It is detoxified mainly by formation of sulfate- and glucuronide-conjugates. Furthermore, Paracetamol-induced liver injury is commonly used as models for investigation the efficacy of hepatoprotective drugs (30). A number of drugs or chemicals such as melatonin, vitamin $\mathrm{E}$ and $\mathrm{N}$-acetyl-cysteine have been used to prevent paracetamol-induced hepatic and renal injury (31).

However, the liver is a multi-use organ of the body is busy with organizing the internal chemical environment. Therefore, damage to the liver influenced by a hepatotoxic agent is of dangerous consequence (32). Toxic liver's drugs such as D-galactosamine and acetaminophen decline the functional capacity of the liver, which leads to the accumulation of waste products such as ammonia in the blood. Paracetamol is a factor analgesic and antipyretic known to owning hepatotoxic effects in humans at overdoses. It has been used as experimental style to assess the efficiency of the liver protection factors. Anyhow, the mode of work of paracetamol on the liver is by covalent link its toxic metabolite (n-acetyl-P-benzoquineune amine) with the Group of sulfhydrl group with protein produced in cell necrosis and lipid peroxidation because the liver injury caused by a high dose of paracetamol. Whilemean,the transfer function of hepatic cells obtained as a result of turbulent plasma leakage at the dinner, so cause an increment in serum enzyme levels (33).

However, in the present study, we assessed whether the heptatotoxic effects caused by administration of paracetamol could be prevented or 


\section{University of Thi-Qar Journal Vol.11 No.2 June 2016}

Web Site: https://jutq.utq.edu.iq/index.php/main Email: journal@jutq.utq.edu.iq

ameliorated by treatment with fluvastatin. Results were displayed at one day post parcetamol induction, the serum levels of hepatocellular albumin marker was significantly declined in group II that treated with aparacetamol alone, while this study was showed that bilirubin serum level was significantly increment, in addition, hepatic serum enzymes(AST,ALT and ALP) where took the same manner. That is Confirming the exhausted of the liver function in compared to group I (negative control) (Table1). These findings are accorder with the consequences of a previous study in which paracetamol was administered to rats (31).

Administration of fluvstatin at concentrations of 10 and $20 \mathrm{mg} / \mathrm{kg}$, p.o., daily resulted in a significant reduction of paracetamol induced elevation of serum enzyme markers, comparable to group II. It is Documented to have a protective effect on plasma membrane of hepatocytes (25). Hepatic injury induced by paracetamol caused a decrease in albumin. Liver transaminases such as AST (aspartate transaminase) or SGOT (serum glutamic oxaloacetic transaminase), and ALT (alanine transaminase) or SGPT (serum glutamic pyruvic transaminase) have still stayed the gold criterions for the evaluation of liver injury (32). However, numerous studies proposes inhibiting influences of statins on proinflammatory cytokine production, such as IFN- $\gamma$, tumor necrosis factor- $\alpha$, interleukin (IL)-1 $\beta$, and IL-6 in multiple cells, including microglia, astrocytes, and mononuclear cells. Accordingly, statins owned many preventative effects including neuro and pulmonary protection. They were reducing neutrophil influx which might have a strong effect on alleviating the downstream inflammatory events, such as macrophage influx, lymphocyte activation and inhibition of cytokine release $([34,35)$. The inhibition of IL-6, IL-8 and GM-CSF expression by statins has been shown in human cell cultures. Statins also affected IL-6 levels in the systemic circulation exert anti-oxidative effects and inhibit apoptosis (36). Statins could plausibly affect these pathways through their inhibition of intracellular prenylation and inhibition of the GTP-binding proteins that underlie these inflammatory pathways (37). Moreover, 3-hydroxy-3-methylglutaryl coenzyme A (HMG-CoA) reductase inhibitors (statins) protect the brain against ischemic injury by upregulating endothelial nitric oxide synthase (eNOS. Ischemic lesion volumes and neurologic deficiencies were significantly reduced in mice by both simvastatin and atorvastatin. Statins increased eNOS and tPA mRNA levels but did not change mRNA levels of 


\section{University of Thi-Qar Journal Vol.11 No.2 June 2016}

Web Site: https://jutq.utq.edu.iq/index.php/main Email: journal@jutq.utq.edu.iq

PAI-1(38sss, 39). So, the hepatoprotective effects of fluvastatin could be ascribe to its interference with many pro- and inflammatory mediators which preceded hepatotoxicity.

\section{Conclusion}

The results of current study proposes that in rats, statins (fluvastatin) owns improving effects on PCM-induced hepatotoxicity when given up to 24hrs post-ingestion, and could have similar effects in humans. Those influences were probably due to the antioxidant activities of fluvatstin. However,. This refers to the activity of fluvastatin contributes significantly to its antioxidant trait. Together, the absence of liver damage and supportive evidence of its antioxidant properties may propose the potential applications of fluvastatin against PCM-induced hepatotoxicity.

تم اختيار هذه الدراسة للنحقق في التأثير الوقائي المحتمل لعقار الفلوفستاتين على الجرعات السمية للبار اسيتول على كبد الجرذان.

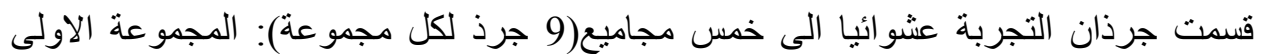

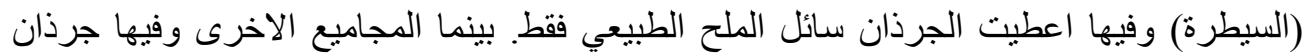

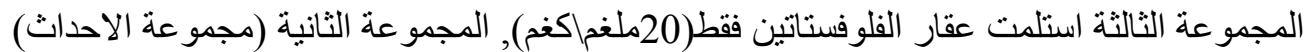

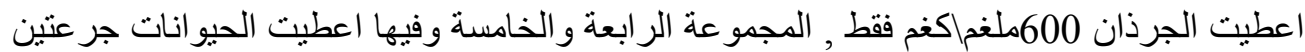

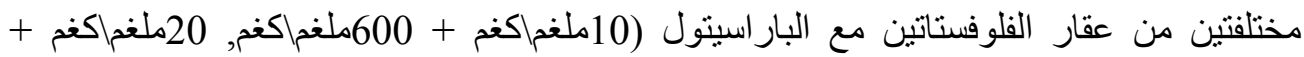
6006لغم/كغم) على التو الي ولمدة 4 اسبوع.

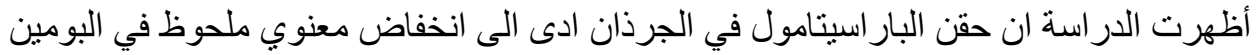

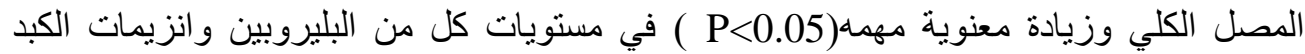

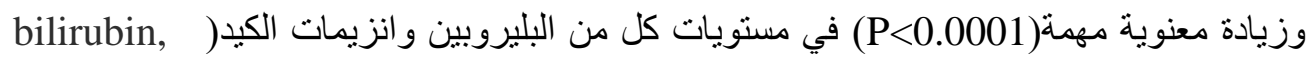

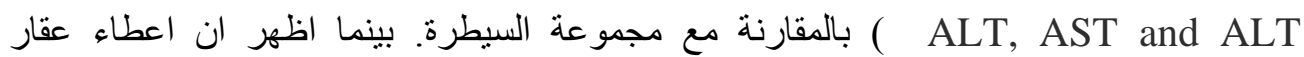

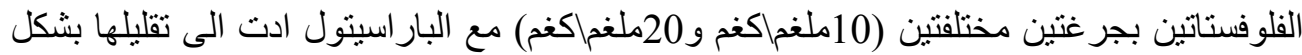
هام معنويا" وبتأثثر معاكس لتلك المستويات. 


\section{University of Thi-Qar Journal Vol.11 No.2 June 2016}

Web Site: https://jutq.utq.edu.iq/index.php/main Email: journal@jutq.utq.edu.iq

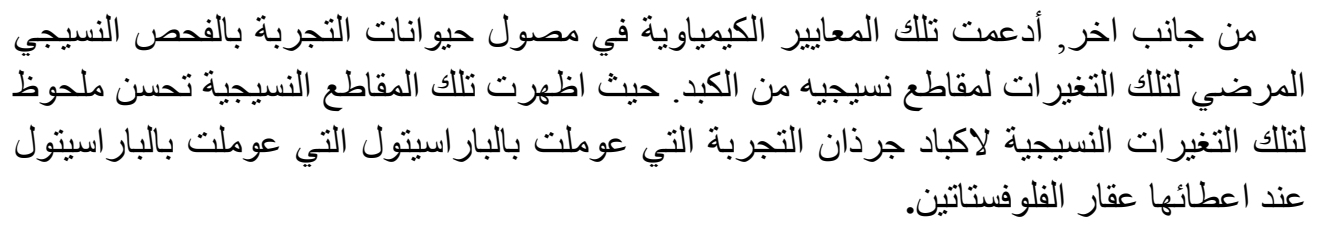

\section{References}

1. Wolf PL. Biochemical diagnosis of liver diseases. Ind J Clin Biochem. 1999; 14:59-90.

2. Daly FF, Fountain JS, Murray L, Graudins A, Buckley NA (March 2008). "Guidelines for the management of paracetamol poisoning in Australia and New Zealand-explanation and elaboration. A consensus statement from clinical toxicologists consulting to the Australasian poisons information centres". Med. J. Aust. 188 (5): 296-301.

3. Khashab M, Tector AJ, Kwo PY (March 2007). "Epidemiology of acute liver failure". Curr Gastroenterol Rep 9 (1): 66-73. .

4. Hawkins LC, Edwards JN, Dargan PI (2007). "Impact of restricting paracetamol packs sizes on paracetamol poisoning in the United Kingdom: a review of the literature". Drug Saf 30 (6): 465-79.

5. Larson AM, Polson J, Fontana RJ, et al (2005). "Acetaminopheninduced acute liver failure: results of a United States multicenter, prospective study".Hepatology 42 (6): 1364-72.

6. Dart RC, Erdman AR, Olson KR, Christianson G, Manoguerra AS, Chyka PA, Caravati EM, Wax PM, Keyes DC, Woolf AD, Scharman EJ, Booze LL, Troutman WG (2006). American Association of Poison Control Centers "Acetaminophen poisoning: an evidencebased consensus guideline for out-of- hospital management". Clin Toxicol (Phila) 44 (1): 1-1

7. Tenenbein M (2004). "Acetaminophen: the $150 \mathrm{mg} / \mathrm{kg}$ myth". J Toxicol Clin Toxicol 42 (2): 145-48.

8. Watkins PB, Kaplowitz N, Slattery JT, et al (2006). "Aminotransferase elevations in healthy adults receiving 4 grams of 


\section{University of Thi-Qar Journal Vol.11 No.2 June 2016}

Web Site: https://jutq.utq.edu.iq/index.php/main Email: journal@jutq.utq.edu.iq

acetaminophen daily: a randomized controlled trial". JAMA 296 (1): 87-93

9. Dart RC, Bailey E (2007). "Does therapeutic use of acetaminophen cause acute liver failure?" Pharmacotherapy 27 (9): 1219-30.

10. Fiorucci S, Antonelli E, Mancarelli A, Palazzeti B,Alvarez-Miller L, Muscara M, Del Soldato P, Sanpaolo L, Wallace JL, Morelli A. 2002. A NO-releasing derivative of acetaminophen spares the liver by acting at several checkpoints in the Fas pathway. British Journal of Pharmacology; 135: 589-599

11. Mitchell JR, Jollow DJ, Potter WZ, Gillette JR, Brodie BB. 1973."Acetaminophen-induced hepatic necrosis. IV. Protective role of glutathione". The Journal of Pharmacology and Experimental Therapeutics,; 187 (1): 211-7.

12. Dai Y, Cederbaum AI : 1995. "Cytotoxicity of acetaminophen in human cytochrome P4502E1-transfected HepG2 cells". The Journal of Pharmacology and Experimental Therapeutics ; 273 (3): 1497505.

13. Richardson, JA:"Management of acetaminophen and ibuprofen toxicoses in dogs and cats" (PDF). Journal of Veterinary Emergency and Critical Care 10 2000;(4): 285-291

14. Smilkstein MJ; Knapp GL; Kenneth Kulig KW; and Rumack BH. 1988. Efficacy of Oral N-Acetylcysteine in the Treatment of Acetaminophen Overdose. N Engl J Med; 319:1557-1562.

15. Suzuki A; Yuen N; Walsh J; Papay J; Hunt CM and Diehl AM. 2009. Co-medications That Modulate Liver Injury and Repair Influence Clinical Outcome of Acetaminophen-Associated Liver Injury. Clin Gastroenterol Hepatol.;7(8):882-888.

16. Zhang JY, Song SD, Pang Q, Zhang RY, Wan Y, Yuan DW, Wu QF, Liu C. 2015. Hydrogen-rich water protects against acetaminophen-induced hepatotoxicity in mice. World $\mathrm{J}$ Gastroenterol.; 21(14): 4195-4209. 
17. Wang Y, Jiang Y, Fan X, Tan H, Zeng H, Wang Y, Chen P, Huang M, Bi H. 2015. Hepatoprotective effect of resveratrol against acetaminophen-induced liver injury is associated with inhibition of CYP-mediated bioactivation and regulation of SIRT1-p53 signaling pathways. Toxicol Lett.; pii: S0378-4274.

18. Matsura T; Nishida $\mathrm{T}$; Togawa A; Horie S; Ohata S; Nakada J, Ishibe $\mathrm{Y}$ and Ohta Y. 2006. Mechanisms of protection by melatonin against acetaminophen-induced liver injury in mice. Journal of Pineal Research; 41(3):211-219.

19. Guzy J; Chovanová Z; Mareková M; Chavková Z; Tomečková V; Mojžišová G and Kušnír J. 2004. Effect of quercetin on paracetamol-induced rat liver mitochondria dysfunction. Biologia, Bratislava; 59(3): 399-403.

20. Al-Snafi AE. 2014. The Pharmacological activities of Alpinia galangal - A review. International Journal for Pharmaceutical Research Scholars; 3(1-1): 607-614.

21. Gupta K, Chitme H, Dass SK, Misra N. 2006. Antioxidant activity of Chamomile recutita capitula methanolic extracts against $\mathrm{CCl} 4-$ induced liver injury in rats. J Pharma Toxicol.;1:101-7.

22. Roglans N, Sanguino E, Peris C, Alegret M, Vazquez M, Adzet $\mathrm{T}$, et al.: 2002. Atorvastatin treatment induced peroxisome proliferator-activated receptor alpha expression and decreased plasma nonesterified fatty acids and liver triglyceride in fructosefed rats. J Pharmacol Exp Ther ; 302(1):232-9.

23. Egawa T, Toda K, Nemoto $\mathrm{Y}$, Ono M, Akisaw N, Saibara T. 2003. Pitavastatin ameliorates severe hepatic steatosis in aromatase-deficient (Ar-/-) mice. Lipids 38(5):519-23.

24. Gomez-Dominguez E, Gisbert JP, Moreno-Monteagudo JA, GarciaBuey L. 2006. Moreno-Otero R:A pilot study of atorvastatin 


\section{University of Thi-Qar Journal Vol.11 No.2 June 2016}

Web Site: https://jutq.utq.edu.iq/index.php/main Email: journal@jutq.utq.edu.iq

treatment in dyslipemid, non-alcoholic fatty liver patients. Aliment Pharmacol Ther. 23(11):1643-7.

25. Hyogo H, Tazuma S, Arihiro K, Iwamoto K, Nabeshima Y, Inoue M, 2008, . Efficacy of atorvastatin for the treatment of nonalcoholic steatohepatitis with dyslipidemia. Metabolism 57(12):1711-8.

26. Sabin, landan of Brian, and Everit, S. [Edit]. 2004. A Handbook of statistical analyse lesing SPSS, chapman of Hell CRC, was hington.

27. Mitchell JR, Jollow D, Potter WZ, Gillette JR, Brodie BB. 1973. Acetaminophen-induced hepatic necrosis. IV. Protective role of glutathione. J Pharmacol Exp Ther.; 187, 211-217.

28. Comporti M, Mallard E, De Belo B, Casino AF. 1991. Glutathione depletion: its effects on other antioxidants systems and hepatocellular damage. Xenobiotica; 21: 1067-1076

29. Mayne PD. 1994. The liver and gall stones. In: Clinical Chemistry in diagnosis and treatment. 6th edition, London: Edward Arnold, (A division of Hoddler Headline Plc), London.: 279-298.

30. Dixon MF; Nimmo J and Prescott LF. 1971. Experimental paracetamol-induced hepatic necrosis: A histopathological study. J Pathol; 103: 225-229

31. Sener, G., Sehirli, A.Ö., Ayanog ${ }^{` l u-D u ̈ l g e r, ~ G ., ~ 2003 . ~ P r o t e c t i v e ~}$ effects of melatonin, vitamin $\mathrm{E}$ and $\mathrm{N}$-acetylcysteine against acetaminophen toxicity in mice. A comparative study. J. Pineal. Res. 35, 61-68.

32. Michaut, A., Moreau, C., Robin, M.-A., Fromenty, B., 2014. Acetaminophen-induced liver injury in obesity and nonalcoholic fatty liver disease. Liver Int... http://dx.doi.org/10.1111/liv.12514.

33. Kapur, V., Pillai, K.K., Hussian, S.Z., Balani, D.K., 1994. Hepatoprotective activity of "Jigrine" on liver damage caused by alcohol-CCl4 and paracetamol in rats. Indian J. Pharmacol. 26, 3540.

34. Howell, B.A., Siler, S.Q., Shoda, L.K.M., Yang, Y., Woodhead, J.L., Watkins, P.B., 2014. A mechanistic model of drug-induced liver injury aids the interpretation of elevated liver transaminase 


\section{University of Thi-Qar Journal Vol.11 No.2 June 2016}

Web Site: https://jutq.utq.edu.iq/index.php/main Email: journal@jutq.utq.edu.iq

levels in aphase I clinical trial. CPT Pharmacometrics Syst. Pharmacol. http://dx.doi.org/10.1038/psp.2013.74.

35. Maher BM; Ni Dhonnchu T; Burke JP; 2009. Statins alter neutrophil migration by modulating cellular Rho activity - a potential mechanism for statins-mediated pleiotropic effects? J Leukoc Biol; 85: 186-193.

36. Chello M; Patti G; Candura D; 2006. Effects of atorvastatin on systemic inflammatory response after coronary bypass surgery. Crit Care Med;34: 660-667.

37. Jollow DJ; Thorgeirsson SS; Potter WZ; Hashimoto M and Mitchell JR. 1974. Acetaminophen induced hepatic necrosis VI. Metabolic disposition of toxic and non- toxic doses of Acetaminophen. Pharmacology; 12: 251-271.

38. Guasti L; Marino F; Cosentino M; 2006. Simvastatin treatment modifies polymorphonuclear leukocyte function in high-risk individuals: a longitudinal study. J Hypertens; 24: 2423-2430.

39. Asahi M; Huang Z; Thomas S; Yoshimura S; Sumii T; Mori T; Qiu J; Amin-Hanjani S; Huang PL; Liao JK; Lo EH and Moskowitz MA. 2005. sProtective effects of statins involving both eNOS and tPA in focal cerebral ischemia. J Cereb Blood Flow Metab; 25(6):722-729. 